\title{
Nursery Rhymes as a Vehicle for Teaching English as a Foreign Language
}

\author{
Najat Ismael Sayakhan, Department of English, College of Basic Education, University \\ of Sulaimani, Iraqi Kurdistan Region
}

Darcy H. Bradley, Eastern Washington University, Washington, USA

Email: najat.sayakhan@univsul.edu.iq, dbradley@ewu.edu (D. H. Bradley)

\begin{abstract}
In this paper, the authors present a rationale and offer suggestions for how nursery rhymes could be used in the EFL classroom as well as how teachers and/or teachers in training might use nursery rhymes to enhance engagement in learning English. First, the authors define nursery rhymes, give a brief history of the origins, discuss the characteristics, make a case for using nursery rhymes with EFL learners, and last, offer practical suggestions for how nursery rhymes might be used in English as a Foreign (EFL) instruction. A list of accessible nursery rhyme resources is shared at the end. There are many categories in folklore, but the ones children often like the most and adults may remember well are nursery rhymes, fairy tales, fables, myths, legends, and folksongs. Each of these genres contributes in some way to the language development of children. Nursery rhymes in particular form one of the foundations of children's as well as adults' literary heritage. The simple rhythm and rhyme of the language, the often predictable structure of the narratives, and the appealing characters combine to produce memorable language models for young children (Cullinan \& Galda, 1998; Temple, Martinez, \& Yakota, 2011). Children delight in the opportunities to chant the catchy phrases, mimic the nonsense words, and recite the lines endlessly. This pleasure in nursery rhymes translates into developing many reading, writing and oral language skills such as naturally segmenting sounds in spoken words and playing with real and nonsense words. Additionally, young children appreciate the stories and verses for their rhythm, repetition, and rhyme. Their attention is focused on the fanciful language and imaginative nonsense. They learn basic story patterns, encounter vivid plots, develop a sense of theme, and meet intriguing characters that in turn
\end{abstract}


become the stepping stones for subsequent literary education (Cullinan \& Galda, 1998; Bodden, 2010).

Keywords: Nursery Rhymes, teaching English, EFL, young learners, rhyme, rhythm

\section{Definition and Types of Nursery Rhymes}

A nursery rhyme is defined as a short poem or song for children. Additionally, it is usually composed by anonymous poets; nursery verses are highly rhythmic, tightly rhymed, and popular with small children (Temple, Martinez, and Yokota: 171). Considered traditional poems for young children in Britain and many other countries, their usage dates from the 19th century and in North America the older 'Mother Goose Rhymes' are still often used in primary classrooms. Betsy Hearne emphasizes the appeal of these rhymes and notes that "Nursery Rhymes are only a step away from song in their changing cadence and compressed story elements" (cited in Norton's Through the Eyes of a Child: 160). Whereas lullabies are considered sleep songs, nursery rhymes are waking songs; they are verses for an adult to sing or chant in a game with a child. Many of these anonymous verses have echoed through the generations; one can often find the echoes of these poems in collections by later poets (Zipes, et al: 1138).

In addition to the supportive concepts of rhyme, rhythm and song-like attributes nursery rhymes offer young learners, older English language learners can also benefit from these supports. Many nursery rhymes have a long tradition of political meanings, which can make them more interesting for adult learners.

\section{Historical Background:}

Poems have been composed for thousands of years. In the past, when people intended to tell a tale, they made it into a poem, because of the power poems have on readers. They can help readers see and mentally explore things in a new way. They can make readers cry or laugh, sigh or even scream (Bodden: 3). One of the goals of silly poems known as nursery rhymes is to entertain young children and soothe babies. It is believed that the earliest nursery rhymes were created before the 1600s. The first rhymes belong to the oral tradition; they were passed on by word of mouth from generation to generation. Many nursery rhymes, however, were not originally created 
for children. Some were parts of adults' songs. Others were taken from the cries of vendors or peddlers in the streets. Some were parts of old religious traditions. Over time, nursery rhymes became part of the daily lives of children; they recited those rhymes at home, in school, and at play in the streets.

In the beginning of the 1700s a few of the rhymes were published in England as $\boldsymbol{A}$ Little Book for Little Children, it contained a number of nursery rhymes that are still recognized today, for example, "Baa, Baa, Black Sheep":

Baa, baa, black sheep, Have you any wool?

Yes, sir, yes, sir, Three bags full.

One for the master, and one for the dame,

And one for the little boy who lives down the lane.

This traditional nursery rhyme dates from feudal times, when peasants and vassals paid shares of their products to the powerful land lords and their family who owned the lands of England. Other nursery rhymes also have a rich historical background and "hidden" messages. Consider the following verse; it refers to the Black Death, or the Plague, which killed about a fourth of the population of England in the fourteenth century:

Ring around the roses,

Pocket full of posies,

Ashes, ashes,

We all fall down.

The ring around the roses refers to the rash of an infected person; the pocket full of posies refers to the alleged protection flowers offered against polluted air which was believed to spread the sickness; and the ashes and falling down refer to the sudden dramatic death of plague-stricken people whose bodies were piled up and burned (Temple, et.al.:171). During 1765-1780 a collection of rhymes called Mother Goose's Melody was published in England by John Newbery. It witnessed an instant success and copies were soon being sold throughout England and in 
America. Although writing new nursery rhymes is not common, today the old ones continue to be recited again and again by children and teachers around the world (Bodden: 9). This meaningful history may help learners of English language appreciate the value of learning and using nursery rhymes in speaking, reading and writing.

\section{Appealing Characteristics:}

Nursery rhymes take no consistent form. Some are short, with four or fewer lines. Others are long and contain many verses. Most nursery rhymes are musical, with a strong sense of rhyme and rhythm. These characteristics make nursery rhymes easy and delightful to remember (Bodden: 10). Some nursery rhymes follow the scheme of using couplets (the last words of the first two lines rhyme; the last words of the last two lines rhyme; or used the a a b b rhyme structure). This type of rhyme scheme is presented in the following example:

Little bird of paradise,

She works her work both neat and nice;

She pleases God, she pleases man,

She does the work that no man can.

(Gould and Gould:272)

Along with the fun rhymes this sort of poetry has, it usually has a strong sense of rhythm. The rhythm of nursery rhymes is often like the beat of drums. This beat keeps the poem active and moving forward. The combination of stressed and unstressed syllables of a nursery rhyme helps make up its rhythm (Bodden: 13). Nursery rhymes usually do not follow a specific rhythm. Reading them out loud can help one identify its rhythm. In fact, since nursery rhymes were originally passed along orally, they are usually meant to be heard rather than simply seen on a page (Ibid: 15).

The rhythm in many nursery rhymes invites listeners to react immediately. They may, for example, clap their hands or jump up and down to the music of lines such as these: 
Handy dandy, Jack-a-Dandy

Loves plum cake and sugar candy;

He bought some at a grocer's shop

And out he came, hop, hop, hop (Norton:160).

The rhyming words dandy and candy, and shop and hop, engage listeners or readers to join in and play with or use these rhyming words to make their own rhymes. A child may also respond to the repetition of sounds in a phrase or line of a nursery rhyme by saying them over and over.

The imaginative use of words and ideas is another characteristic of nursery rhymes. Children enjoy the images depicted by the following lines of verse:

Jack and Jill went up the hill

To fetch a pail of water.

Jack fell down and broke his crown,

And Jill came tumbling after.

It is easy to envision a girl and a boy climbing a hill bucket in hand, ready to draw water from the well when a trip and fall ends the mundane task.

Nursery rhymes tend to have a compact structure. The setting in nursery rhymes is established very quickly and the plot of the story the rhyme tells is disclosed immediately without further details. Characters are easily identified. In ten short lines one can hear the entire story of the nursery rhyme:

Ding, dong, bell,

Pussy's in the well.

Who put her in?

Little Johnny Flynn 
Who pulled her out?

Little Tommy Stout.

What a naughty boy was that,

Try to drown poor pussy cat,

Who ne'er did any harm

But killed the mice in the farmer's barn.

Humor is another great appeal of nursery rhymes. Hyperbole, the use of exaggeration to highlight the effect, is common in these rhymes. Children as well as adult appreciate ridiculous, exaggerated situations; consider the following famous example:

Hey, diddle, diddle!

The cat and the fiddle.

The cow jumped over the moon;

The little dog laughed

To see such sport,

And the dish ran away with the spoon.

Exaggeration along with rhyme, repetition, and humor combine to create attractive topics, events and characters for young children (Norton: 160).

Another quality that makes nursery rhymes attractive is the witty and whimsical characters that appear in these rhymes. The humorous aspect appeals to the children as well as to the adults who share the verses with them (Cullinan and Galda: 169); for example, listeners or readers may wonder why skinny Jack Spratt couldn't eat any fat while his very large wife could eat no lean or why would an old woman live in a shoe, with a number of children to boot? And of course, does anyone besides Gregory Griggs need twenty-seven different wigs?

$$
\text { Gregory Griggs, Gregory Griggs, }
$$


Had twenty-seven different wigs.

He wore them up, he wore them down,

To please the people of the town;

He wore them east, he wore them west,

But he never could tell which he loved best.

Nursery rhymes have been written about different subjects from people and animals to weather and superstitions. These rhymes cover a wide area of emotions including joy, sadness, fear, and love. But no matter how serious their subject matter, most nursery rhymes are lighthearted (Bodden: 16). Some nursery rhymes tell stories about real people. Others are about made-up or fictitious characters. Some are about things that actually happened, others are complete nonsense. Some nonsense rhymes consist of made up words ('diddle, diddle' for instance), others contain ridiculous or impossible situations (like 'the cow jumped over the moon') (Ibid: 17).

\section{Teaching Nursery Rhymes:}

A parent would never read to their child a story of a man who sat on a wall and who fell down and broke into pieces and no one could help him. Yet, as a nursery rhyme, "Humpty Dumpty" has been children's favorite for generations. The silliness of the rhyme and nonsense language don't matter for young children, the melody and rhythm are the focal points. Nursery rhymes have a lot more to offer than just entertainment value. These rhymes introduce children to the idea of narrative, promote social skills, enhance language development, and lay the basis for learning to read and spell (http://www.thedesignshoppe.com).

\section{Practical Applications}


Listening to and reciting nursery rhymes enhances early reading skills and phonemic awareness which is said to predict a child's reading success. Yet any age learner can benefit from using nursery rhymes to develop or improve English pronunciation, word play, and more.

Whether teaching young children or older learners, nursery rhymes have a place in learning or acquiring English language skills. Here are some ideas a teacher might try with her/his class.

First, teachers should be willing to read aloud a variety of nursery rhymes - not just once - but many times. The beginning for all language learning is oral. Hearing and joining in with the teacher's voice is a critical component for learning to read and write and an important starting point for helping students use the cadence, structure, and intonations of Standard English.

Pocket charts have a place in any classroom for playing with language, teachers might write nursery rhymes on paper strips, assemble with readers as a group or have individuals come up and read and put their strips in the right lines in the pocket chart. Practice reading the pocket chart strips in the correct order. Once readers are fairly fluent, the teacher might have them recognize the order and try reading each line and see how it sounds. She/he reassembles again correctly, with student help and make sure students read the line before placing or replacing it in the pocket chart.

Readers' theatre can be used for beginning child or adult EFL readers. The teacher might choose one or two popular nursery rhymes, make sure everyone has a copy of the poem, and practice fluent reading with appropriate intonation, expression, and pacing until each group can perform for an audience of peers or others. The power of readers' theatre is that readers of all stages can work together to create an enjoyable performance for others while practicing the lines. Video or audio-tapes can be made so that performers can listen to and evaluate their performance.

The teacher might have learners choose a nursery rhyme they would like to memorize, practice saying it or reading it until fluent, then share in small groups. Students can put physical actions to the nursery rhyme as someone reads it aloud. The teacher might give different nursery rhymes to small groups and have them practice reading the poem and acting it out, then share it in small groups or with the whole class. 
Older students who can read and write in their heritage language can translate a nursery rhyme from their language to English, alone or in small teams, ensuring that the poem rhymes appropriately. Conversely, students can translate an English nursery rhyme into their mother tongue and share it with other students (can work in teams or alone).

Another idea is to explore the political history of one of the English nursery rhymes and make a poster where an explanation is written for each line.

Students can also put physical actions to the nursery rhyme as someone reads it aloud. The teacher can give different nursery rhymes to small groups and have them practice reading them and acting them out and then share them with the rest of the class.

Nursery Rhymes can be one part of TEFL to adult learners. Since nursery rhymes are such a fundamental part of exploring English and they occur in many other languages and cultures, they are a natural vehicle for engaging learners of English, no matter what their language or cultural background is. Nursery rhymes can help older learners develop cultural appreciation as well as an enjoyable way to practice with the new language.

This form of light verse can assist older students and adults to learn English. This kind of redundancy in language is also what assists older learners of English to access the new language.

In addition to the supportive concepts of rhyme, rhythm, and song-like attributes nursery rhymes offer young learners, older English language learners can also benefit from these supports. Some nursery rhymes have a long tradition of political meanings, which can make them more interesting for adult learners. This meaningful history may help learners of English appreciate the value of learning and using nursery rhymes in speaking, reading and writing.

\section{Conclusion}

There is overwhelming evidence that early learning of nursery rhymes, songs, chants and rhythmic poems significantly enhances early reading skills and phonemic awareness. Since oral language precedes written text, the teaching of nursery rhymes is considered an important tool to teach English as a foreign language to young learners from kindergarten through third grade 
because of the magic of these rhymes which have a number of characteristics; they have rhyme and rhythm and can be sung to familiar tunes, they have short, simple, rhyming text that is easy to memorize, they can teach story structure and elements (introduction, setting, plot, and character), they are fun for word play, they extend and enrich student vocabularies, they are perfect for pocket charts, they provide instant reading success for most students, and they are perfect for teaching basic skills, including: phonemic awareness (hearing sounds), phonics (working with sounds), word families and/or chunks, syllabification, concepts about print (leftto-right progression, tracking, one-to-one), and also correspondence, return sweep (where to go at the end of a line), letters versus words, capitalization, and many other important concepts.

\section{References}

- Cullinan, Bernice E. and Lee Galda. Literature and the Child (4 $4^{\text {th }}$ ed.): Harcourt Brace College, New York. 1998.

- $\quad$ Bodden, Valerie. Nursery Rhymes: Creative Education, Minnesota, USA. 2010.

- Temple, Charles, Miriam Martinez, and Junko Yokota. Children's Books in Children's Hands: An Introduction to Their Literature ( $4^{\text {th }}$ Ed.). Pearson, New York. 2011.

- Williams S. Baring-Gould and Ceil Baring-Gould. The Annotated Mother Goose. Clarkson N. Potter, Inc. New York. 1962.

- Norton, Donna E. Through the Eyes of a Child: An Introduction to Children's Literature ( $8^{\text {th }}$ ed.): Pearson, New York. 2011.

- Zipes, Jack, Liss Paul, Lynne Vallone, Peter Hunt, and Gillian Avery. The Norton Anthology of Children's Literature: The Traditions in English. W. W. Norton \& Company, Inc. New York. 2005.

- Huck, Charlotte S., Susan Hepler, Janet Hickman, Barbara Z. Kiefer. Children's Literature in the Elementary School (6 ${ }^{\text {th }}$ Ed.). Brown \& Benchmark. Chicago. 1997

- Antonia Van Der Meer. Parents Magazine: 'Why Children Need Nursery Rhymes? Gruner \&Jahr Publishing. New York. 1999.

- Meer. A. Van Der. "Why Children Need Nursery Rhymes" http://www.thedesignshoppe.com 


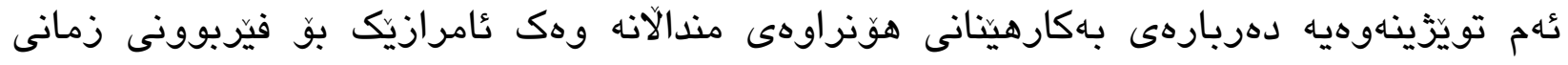

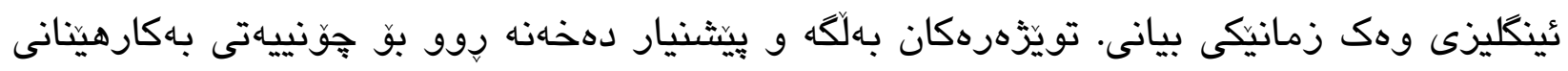
هوَنراوهى مندالآن له لايهن ماموّستايانهوه له يُولهكانى فيرّكردنى زمانى ئينكليزى وهك زمانى بيانى و ئهو عاسانكارييهى مامؤستايان دهيكهن له فيركردندا.

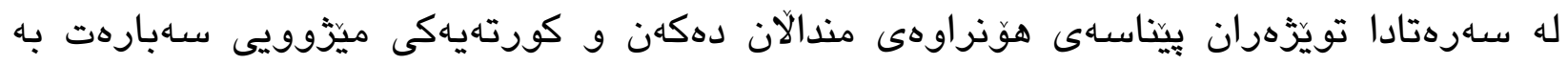
بنجينهكانى ئهم هوَنراوانه دهخهنه بهرجاوى خوينّهر و دواتر خهسلهته ديارهكانى شيدهكهنهوه و كهيسيَكى بهروهردهيى دروستدهكهن بو بهكارهينانى هوّنراوهى مندالآن له فيّربوونى زمانى يُينكليزيدا. له كوَتاييدا جهاند يِيشنياريّك دهخهنه روو بو شيّوازى بهكارهينانى ئهم هوَنراوانه وهك ئامرازيك بو فيّربوونى زمان له يِلى زمانى يُينكليزيدا. تويَزينهوهكه كوتاييديّت به ليستيك لهو سهارجاوانهى بهكارهاتوون بو ئهنجامدانى ئهم تويّزينهوهيه.

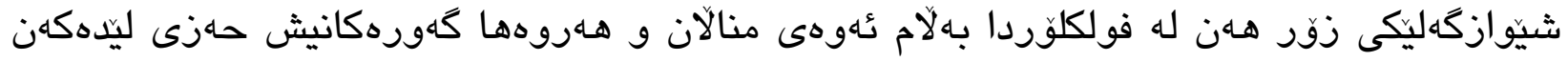
هوَنراوهى مندالآن و ئهسـانه و جيروك به زمانى كَيانداران و داستان و لايلايه و كَورانى فولكلوريه. هـه يهك لهمانه يشكى خوّى بهركهوتووه له كَهشهيّدانى زمانى مندالآندا, له سهرووى هـمووياندا

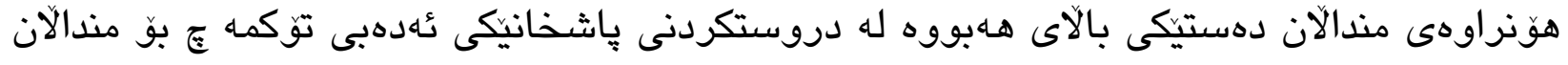

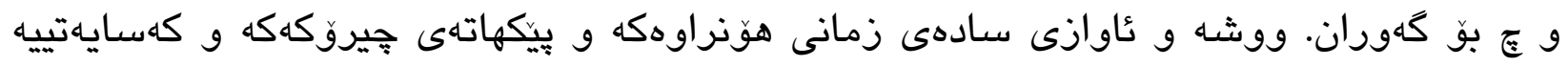
سهرنجراكيجشاهكانى ناو هوَنراوهكه هـهوو به يهكهوه نموونهيهكى زمانهوانى له بيرنهكراو بهرهام دههينّن بوّ مندالَكان. ووشهكليلييهكان: هوَنراوهى مندالآن , فيّركردنى زمانى ئينكليزى وهك زمانى بيانى , فيّرخوازى بجووك , كيش و سهروا 


\section{ملخص البحث}

يتناول البحث استخدام قصائد الاطفال كوسيلة أو أداة لتعليم اللغة الانجليزية كلغة أجنبية حيث تقدم الباحثثان أدلة و مقترحات حول كيفية استخدام قصائد الاطفال من قبل المعلمين فى دروس اللغة الانجليزية و التسهيلات التي يقدمها المعلمون في تعليم اللغة. في البداية تقدم الباحثتان تعريفا شاملا لقصائد الاطفال و يليها موجزا تاريخيا حول الاصول القديمة لهذه القصائد ومن ثم تقدمان تحليلا لخصائص و ميزات هذه القصائد حيث تعتمدان منهجا تربويا لاستخدام هذه القصائد في تعليم اللغة الانجليزية. وفي الختام تعرض الباحثتان عدة مقترحات لكيفية استخدام قصائد الاطفال كأداة لتعليم اللغة.

يتخذ الارث الثقافي اشكالا عدة ولكن الابرز و الاقرب لقلوب الطفال و الكبار على حد سو اء هي قصائد الاطفال و الاساطير و حكايات الجان (الخزعبلات) و الخرافات و الاغاني الفلكلورية و التهويدات و التي تترسخ في ذاكرتهم حيث يسهم كل لون من هذه الاوان في تتمية اللغة لدى الطفل و قصائد الاطفال لها النصيب الاوفر في المخزون الادبي للاطفال و الكبار معا. الكلمات الجميلة و الوزن و القافية المحبية وحبكة القصة و الثخصيات الملفتة للانظار في القصة الثعرية تعمل على خلق نموذج لغوي متين غير قابل للنسيان. الكلمات المفتاحية: قصائد الاطفال , لتعليم اللغة الانجليزية كلغة أجنبية , المتعلم الصغير , الوزن و القافية 